Erzsébet Csatlós*

\title{
ORGANISATIONAL PRINCIPLES \\ IN EUROPEAN ADMINISTRATION: FOCUSING ON FOREIGN POLICY ORGANS AND THE ADMINISTRATIVE PROCEDURE OF CONSULAR PROTECTION IN THIRD COUNTRIES ${ }^{1}$
}

\section{Introduction}

The European Union (EU) is a sui generis international organisation. Its powers are transferred from Member States and this also limits its functioning. The EU has a limited number of institutions and many organs and bodies to perform common tasks but, basically, the administration of Member States is responsible for executing the EU law. ${ }^{2}$ However, the relationship of the EU institutions, organs and bodies and the competent national authorities varies from policy to policy, so it is hard to find principles that can describe the organisational structure in the same way as in Member States.

* Erzsébet Csatlós - PhD, University of Szeged, Faculty of Law and Political Sciences, Department of Public Administrative Law, Hungary.

1 "Supported by the UNKP-17-4 New National Excellence Program of the Ministry of Human Capacities".

2 European Principles for Public Administration, SIGMA Papers: No. 27, CCNM/ SIGMA/PUMA(99)44/REV1. 1999 [SIGMA 27], p. 5. 
Foreign policy has a unique position among others as it is still the greatest sphere of state sovereignty. Meanwhile, the Lisbon Treaty introduced major changes, among others, in the institutionalisation of the common policy. Due to its political and diplomatic functions, foreign services are strictly attached to the government and this policy leaves no space for decentralisation, although they are also an important manifestation of the state's administrative services abroad. Recently, on the occasion of consular protection policy in third countries there are debates on expanding the EU delegations' competency to cover some administrative authority tasks. ${ }^{3}$ Therefore, the EU's foreign policy organs and their prospects are being revaluated to avoid a parallel organisational structure. In these circumstances, it is time to examine the organisational structure of the foreign policy organisation in the European administration and to define the major organisational principle that describes its functioning.

\section{Organisational structure of the European administration in the view of principles}

The EU's own executive capacity (direct administration) is relatively small. ${ }^{4}$ The execution, the process of individual cases is, therefore, left to the administrative capacity of Member States' (indirect administra-

3 See, A.M. Fernández, Consular Affairs in the EU: Visa Policy as a Catalyst for Integration?, The Hague Journal of Diplomacy, Vol. 3, No. 1, 2008 (pp. 21-35), pp. 28-34.

${ }^{4}$ As the guardian of the Treaties, the European Commission is responsible for the proper execution of the EU law, in fact, each Commissioner is responsible for specific policy areas to defend the interests of the EU as a whole while they are in charge of drafting and monitoring proper execution by the Member States. The Commission is entitled to establish agencies for technical, scientific, or administrative function to help the EU institutions in policy formation, law-making and execution. See the consolidated version of the Treaty on the Functioning of the European Union, OJ C 326, 26.10.2012 (pp. 47-390), [TFEU] Art. 352. Sometimes they are called decentralized agencies as their seats are in different Member States, although they are considered central supranational organs and not local ones placed on the territory of all the Member States. European Agencies - The Way Forward, Brussels, Communication from the Commission to the European Parliament and the Council, 11.3.2008. COM(2008) 135 final p. 4; E. Chiti, EU and Global Administrative Organizations, Springer-Verlag, Berlin Heidelberg 2011, p. 21. 
tion). ${ }^{5}$ The correlation of the different levels allows one to describe the $\mathrm{EU}$ as a multilevel administrative system known as European administrative space (EAS) ${ }^{6}$ which is held together by common constitutional principles rooted in democratic traditions. These are legal principles whose main function is the attribution of the binary qualification of legal/illegal in the light of overarching values, and ignoring them leads to the loss of legitimacy. ${ }^{7}$ All of them can be traced back to the principle of rule of law and they pervade the functioning of institutions and organs as well as the administrative procedures at all levels. ${ }^{8}$ Direct and indirect administration form relatively separated organisational systems with their own institutional norms, and are mainly connected via governance issues. The system formed by the two levels also assumes

${ }^{5}$ L. Ficzere, Európai közigazgatás - nemzeti közigazgatás, [in:] (eds.) B. Gerencsér, P. Takács, Ratio legis, ratio iuris: ünnepi tanulmányok Tamás András tiszteletére 70. születésnapja alkalmából, Szent István Társulat, Budapest 2011, pp. 383-84.

${ }^{6}$ M. Dezső, A. Vincze, Magyar alkotmányosság az európai integrációban, HvgOrac, Budapest, 2012, p. 490; E.G. Heidbreder, Structuring the European Adminstrative Space: Channels of EU Penetrations and Mechanisms of National Chance, KFG Working Paper Series, No. 5, 2009, p. 5; A. Torma, Az Európai Közigazgatási Térségröl - magyar szemmel, Miskolci Jogi Szemle, Vol. 6, special edition, 2011 (pp. 196-210), p. 197; O. Kárpáti, Az európai közigazgatási tér kialakulása (Part I), Sectio Juridica et Politica, Vol. XXIX/1, Miskolc 2011 (pp. 229-247), p. 234; I. Koprić, A. Musa, G. Lalić-Novak, Good Administration as a Ticket to the European Administrative Space, Zbornik PFZ, Vol. 61, No. 5, 2011 (pp. 1515-1560), pp. 1545-1546; D. Curtin, M. Egeberg, Towards a New Executive Order in Europe?, Routledge, London 2013, pp. 30-32.

7 A. von Bogdandy, General Principles of International Public Authority: Sketching a Research Field, German Law Journal, Vol. 9, No. 11, 2008 (pp. 1909-1939), p. 1912.

${ }^{8}$ Particularly important principles set forth in the jurisprudence of the European Court of Justice, which all Member States must in turn apply domestically when applying the EU law, are, among others: the principle of administration through law; the principles of proportionality, legal certainty, protection of legitimate expectations, non-discrimination; the right to a hearing in administrative decision-making procedures, interim relief, fair conditions for access of individuals to administrative courts, non-contractual liability of the public administration. Basically, main administrative law principles which are set as standard are the following: reliability and predictability (legal certainty); openness and transparency; accountability; and efficiency and effectiveness. SIGMA 27 (1999), p. 8. See also: M.W. Bauer, J. Trondal, The Administrative System of the European Union, [in:] (eds.) M.W. Bauer, J. Trondal, The Palgrave Handbook of the European Administrative System, Palgrave Macmillan, Basingstoke 2015 (pp. 1-28), p. 10. 
the principle of administration through law, which means that public administration ought to discharge its responsibilities according to law. ${ }^{9}$

The concept of EAS comes from the intergovernmental history of the integration when administration was a sphere for domestic affairs and only the uniform implementation was under the supervision of the EU-level institutions. The key for a successful execution of the acquis has always been a properly functioning public administration applying the common constitutional principles. ${ }^{10}$ Recently, the number of policies which requires intensive cooperation and an intermediate networking of the competent authorities at the national and supranational level has been increasing. Direct and indirect administration is linked together and the complexity of this relationship depends on the level of Europeanisation of a certain policy. The various forms of transnational interaction define the concept of composite administration. The administrative cooperation - first in the history of integration - got its legal framework in the Lisbon Treaty as a new competence. ${ }^{11}$ The existence of such relationship between the executive apparatus requires the re-thinking of the concept on a simple European administrative space towards a multilevel European administrative organisation. ${ }^{12}$

The key for the proper functioning of the EU lies in its execution, and its organisation is a crucial element for that. ${ }^{13}$ The organisation

9 SIGMA 27 (1999), p. 9.

10 The Lisbon Special European Council, March 2000, Towards a Europe of Innovation and Knowledge. Presidency Conclusions, Lisbon European Council, 23 and 24 March 2000, paras. 9 and 17: http://eur-lex.europa.eu/legal-content/EN/TXT/ ?uri=uriserv:c10241 (accessed on 10.10.2017); W. Drechsler, Towards a Neo-Weberian European Union? Lisbon Agenda and Public Administration, Halduskultuur, Vol. 10, 2009 (pp. 6-21), pp. 7, 10.

11 E. Csatlós, Perspectives of the Cooperation of National Administrative Authorities in the EU, Jogelméleti Szemle, No. 3, 2016, pp. 45-55; E. Csatlós, Az európai közigazgatási eljárási jog kodifikációja és a hatóságok együttmüködése, Eljárásjogi Szemle, No. 2, 2016, pp. 14-23.

12 Cf. H.C.H. Hofmann, Which Limits? Control of Powers in an Integrated Legal System, [in:] (eds.) C. Barnard, O. Odudu, The Outer Limits of European Law, Hart Publishing, Oxford 2009 (pp. 45-62), p. 45.

13 Improving implementation of the EU policies from the (a) functional perspective by ensuring that rights and policy objectives can be pursued and balanced against 
as such has certain objectives and goals to achieve and is structured on certain principles with a view to achieve these objectives. Therefore, the principles that determine the European administrative organisation shall be examined. Due to the nature of the EU as a sui generis international organisation, ${ }^{14}$ the principles are also unique to those which characterise the administrative organisation of a state. Due to the different competencies and powers in different policies transferred by its Member States, the EU's legislative competences and the influence on their execution are different in each branch. Therefore, the classical centralisation - de-centralisation - de-concentration triumvirate shall not be interpreted neither in a political, nor in an administrative way the same as in a state. However, they meet at one point: the organisational concept of European administration shall also correspond to the rule of law as being one of the major values in the EU.

each other; (b) organisational perspective by ensuring that institutions and bodies are equipped with means to pursue the tasks; (c) procedural perspective by ensuring that the core values and rights are fulfilled and realised through procedural provisions and forms of act; and (d) accountability perspective by ensuring that acts are reasoned and justified, and that there is proper review and control of activities. H.C.H. Hofmann, The future of Article 298 TFEU. Administrative procedures for EU institutions and bodies and integrated administration in the EU, Presentation for the EU Ombudsman/ReNEUAL conference "Towards an EU administrative procedure law?", Brussels, 15-16 March 2012, http://www.reneual.eu/images/Events/ED_Conference_March2012/6.6.pdf (accessed on 15.09.2017), p. 4.

14 Accepting A. von Bogdandy's concept, international institutions should be understood as concretizations of general principles of public law formulated in the tradition of liberal constitutionalism and adapted to the structures and requirements of multilevel systems. In the formulation of international principles for the exercise of public authority, there are three ways of interpretation. The (1) basic rule of law principles govern activities of international institutions which need to be implemented by domestic institutions to have legal effects with respect to the individual. Different principles occur for international institutions whose acts directly affect private subjects. These (2) principles force domestic administrations to consider extra-territorial interests as a response to global interdependence. The (3) third type consists of international legal principles for domestic administrative activity. These are the principles regarding the cooperation of domestic administrations within composite administration. The EU, being a unique political system built on supranational and intergovernmental principles, includes all the three types and their application varies according to policies but the third version's importance is growing, cf. A. von Bogdandy, General Principles..., pp. 1921-1922. 


\section{The dichotomy of autonomy and sovereignty in the view of attribution of power}

"International organizations are unusual creations: generated by and for their member-states, at the same time they often have to compete with those very states that created them." 15 The principle of autonomy of the EU along with the principle of sovereignty of Member States form the axis that basically dominates the functioning and organisation of the execution of the EU policies. The powers transferred from Member States enable the EU institutions to legislate. In certain policies, the EU has exclusive competences, ${ }^{16}$ while in others the competences are shared between the EU and the Member States and the latter can act only if the EU has chosen not to, ${ }^{17}$ and the EU has the weakest powers when it has competence to support, coordinate or supplement the actions of Member States. ${ }^{18}$ There is no general competence in the entire policy area but only with regard to matters specified by the TEU-TFEU provisions. ${ }^{19}$ However, the executive organisation is not regulated by the EU. Member States are required to have administrative systems and public administration institutions capable of transposing, implementing and enforcing the acquis according to the principle of obligatory results (obligation de résultat). ${ }^{20}$

The autonomy of the organisation in administrative issues lays on its organisational and operational acts. The constitutional norms of the EU enable the institutions and organs with the necessary competence to perform their tasks. The organisational acts are performed by institutions and organs which by their very nature have binding effect and create obligations and rights for the organization, its organs,

${ }_{15}$ J. Klabbers, An Introduction to International Institutional Law, CUP, Cambridge 2002, Introduction.

16 TFEU, Art. 3.

17 TFEU, Art. 4.

18 TFEU, Art. 6.

19 See Treaty on the European Union - Treaty on the Functioning of the European Union, List of decision-making procedures by article (updated on 17.12.2009) available at: http://ec.europa.eu/codecision/docs/legal_bases_en.pdf (accessed on 10.10.2017).

20 SIGMA 27 (1999), p. 6. 
officers and also create sub-organs. ${ }^{21}$ The addressee of such norms is within the organization and their effects expand solely on their functioning and interactions. ${ }^{22}$ They cover a broad range, including administrative rules of procedure for institutions and organs, rules creating subsidiary organs and the rules governing their operation, staff regulations and rules, and decisions relating to financial and budgetary arrangements. Operational acts, in contrast, are related to the functions of the organization and most of them are directed to Member States as executors in general responsible for their administration or to individuals. In a public law approach, autonomy of the public authority, i.e. the competence to unilaterally determine the conduct of others, is a core issue in the EU multilevel administrative system as it shall be in conformity with the rule of law and the protection of rights fundamental of individuals. ${ }^{23}$ In fact, the direct exercise of authority by international institutions over individuals is extremely rare, ${ }^{24}$ and the decisions of international institutions do not unilaterally affect private parties, but are addressed to national

${ }^{21}$ It is possible to delegate power, even a discretionary power, yet by entrusting it to bodies other than those which the Treaty has established to effect and supervise the exercise of such power, each within the limits of its own authority, would render that guarantee ineffective. If the high authority retained the right to change the decisions of its subsidiary organs, then the sub-delegation would be lawful. D. Sarooshi, The Essentially Contested Nature of the Concept of Sovereignty: Implications for the Exercise by International Organizations of Delegated Powers of Government, Michigan Journal of International Law, Vol. 25, No. 4, 2004 (pp. 1107-1139), p. 1136.

22 C.F. Amerasinghe, Principles of the Institutional Law of International Organizations, CUP, Cambridge 2005, p. 164. In the EU each institution operates within its own treaty powers, procedures and objectives and must cooperate with the others. The Parliament, the Council and the Commission cooperate closely among themselves and may conclude interinstitutional agreements. The institutions work and interaction is also determined by the institutions' respective rules of procedure and the practices that have evolved over the years. Cf. the consolidated version of the Treaty on European Union, OJ C 202, 7.6.2016, TEU, Art. 13.2; TFEU, Art. 295.

${ }^{23}$ See, Charter of Fundamental Rights of the European Union [EU Charter], OJ C 326, 26.10.2012, Art. 41.

${ }^{24}$ For example, in the field of competition policy the Commission acts as a competition authority to take decisions. See, Council Regulation (EC) No 139/2004 of 20 January 2004 on the control of concentrations between undertakings (the EC Merger Regulation), OJ L 24, 29.1.2004, Art. 4; 8-9. 
administrations. ${ }^{25}$ Basically, non-binding normative acts are issued for Member States for a better implementation, although there are examples to the contrary in the form of the Commission's non-legislative acts. ${ }^{26}$

The European Commission, being the main $\operatorname{actor}^{27}$ of the executive power and administrative issues at the direct administrative level of the EU, is a supranational institution that enjoys substantial autonomy from Member States in its function and organisation. ${ }^{28}$ However, it rather fulfils its function as the initiator of legislation and the verification of executive activity of Member States as the guardian of the Treaties; it rarely practices public authority in the sense of unilaterally governing the conduct of others, even without their consent. However, the Commission can elaborate implementing acts ${ }^{29}$ for the unification of execution and recently, the cooperation of authorities is subject to supporting competence, while basically administration and administrative law is a domestic issue. ${ }^{30}$

${ }^{25}$ S. Cassese, Is There a Global Administrative Law?, [in:] (eds.) A. von Bogdandy, R. Wolfrum, D. von Bernstorff, P. Jochen, M. Goldmann, The Exercise of Public Authority by International Institutions. Advancing International Institutional Law, Springer, Heidelberg 2010 (pp. 761-776), p. 763.

${ }^{26}$ See Z. Xhaferri, Delegated Acts, Implementing Acts, and Institutional Balance Implications Post-Lisbon, Maastricht Journal of European and Comparative Law, Vol. 20, No. 4, 2013 (pp. 557-575), pp. 562-566; See also G. Vosa, Delegated or Implementing Acts? Formal and Substantial Criteria in the Systematic Understanding of EU Legal Acts, Sant'Anna Legal Studies, STALS Research Paper, No. 3, 2015, pp. 1-35.

27 A.J. Gil Ibánez, A közösségi jog ellenőrzése és végrehajtása. A nemzeti és az európai közigazgatások szerepe, Osiris, Budapest 2000, p. 32-33.

${ }^{28}$ E. Grande, M. McCowan, The Two Logics of Multilevel Administration in the EU, [in:] (eds.) M.W. Bauer, J. Trondal, The Palgrave Handbook... (pp. 48-65), p. 49.

29 TFEU, Art. 291, cf. Art. 290 on delegated acts. See also: A. Hardacre, M. Kaeding, Delegated \& Implementing Acts. The New Comitology. EIPA Essential Guide, $5^{\text {th }}$ edition, September 2013; http://www.eipa.eu/files/repository/product/20130904094203_Comitology_Brochure5EN_web.pdf (accessed on 10.09.2017), pp. 12-21; E. Csatlós, Az európai közigazgatási eljárási..., pp. 47-48.

30 TFEU, Art. 197. 


\section{Principle of loyal cooperation to structure European administration}

Despite the common values, the EU is not an administrative union in the sense of a centrally organised administrative system with deconcentrated bodies at sub-levels. The relationship between the actors who have administrative competences in a policy area is unique and cannot be described by the classical principles of state administration. The mere fact that the institutions and organs of direct administration are above domestic administrative structure and are supranational in that sense does not make national authorities subordinate in hierarchy. It does not entitle the EU institutions and organs to act with authority power or practice direction or other powers deriving from the principle of hierarchy within an organisation.

At the local level, it is the Member States' administrative authorities that are engaged in the task of execution. Due to the lack of constitutional basis in the funding treaties for the organisation of execution, structural principles are there to override the former concept of executive federalism towards a unified executive power. These are scholarly abstractions which define legal structures within the positive law in the sense of significant regularities, ${ }^{31}$ and help to fix the margins of interpreting obligations to achieve an "open, efficient and independent European administration". ${ }^{32}$ The key for such is the solidarity among all actors and principle of loyal and sincere cooperation and the coordination making it effective along with the obligation for all actors. Principles cannot create competence and, anyway, measures taken at the EU level must also comply with the principle of subsidiarity. ${ }^{33}$ Principles fill the legal gaps and direct interpretation to achieve the common goal: evaluation of the EU goals.

31 A. von Bogdandy, General Principles..., p. 1911.

32 TFEU, Art. 298.

33 A. McDonnell, Solidarity, Flexibility, and the Euro-Crisis: Where Do Principles Fit In?, [in:] (eds.) L.S. Rossi, F. Casolari, The EU after Lisbon. Amending or Coping with the Existing Treaties?, Springer, Heidelberg 2014, p. 66. 
There are many examples for policy areas with procedures in which decisions are taken on the basis of a procedure with composite elements. Cooperation is the process of entering into a relationship with another institution or organ to achieve a system-derived goal. It means that in many cases, both Member State authorities as well as the EU institutions and bodies contribute to a single procedure, irrespective of whether the final decision is taken at the national or the European level. The complexity of composite procedures and the competences of the indirect actors, and their influence on the work of the national authority in charge to proceed in each case, depend on the policy area and the legislative competence of the EU to regulate it. Judicial review of composite decisions is thus often challenging. ${ }^{34}$ Therefore, the word "cooperation" is used to describe in general the relationship between the actors as the content of it differs considerably from one policy area to another but, basically, all of them have the information sharing mechanism at the heart. ${ }^{35}$ Pure vertical cooperation takes place between the EU Member States' assigned central authorities with the EU institutions and organs in governance issues; while horizontal cooperation is an activity between the actors of the same level: direct-level ones among each other and Member States' competent administrative authorities. The mixture of the two forms a network to a better realisation of the EU aims and execution of the EU law with a coordination centre at direct administration level; this is a common form of composite administrative procedure. Such procedure has existed for a long time in policy-specific rules but were not based on any coherent and comprehensive legal basis until the

${ }^{34}$ H.C.H. Hofmann, Which Limits?..., p. 136. Composite procedures makes the exercise of judicial review significantly more difficult. The reason is that the system of judicial review of administrative action in the $\mathrm{EU}$ is established in a traditional two-level approach: national courts or as courts of the CJEU. Judicial supervision of the actions of the integrated executives in the EU is generally undertaken by Member State courts. Without definitive structural and procedural rules of cooperation, the question of responsibility and finding adequate remedies for judicial review in procedures of composite nature is challenging. See, C.H.C Hofmann, The Court of Justice of the European Union and the European Administrative Space, [in:] (eds.) M.W. Bauer, J. Trondal, The Palgrave Handbook..., p. 301.

${ }^{35}$ H.C.H. Hofmann, Which Limits?..., p. 138; J. Trondal, B.G. Peters, The Rise of European Administrative Space: Lessons Learned, Journal of European Public Policy, Vol. 20, No. 2, 2013 (pp. 295-307), pp. 299-300. 
adoption of the Lisbon Treaty. It introduced supporting competence in administrative matters for the EU in the form of ordinary legislative procedure ${ }^{36}$ without any substantive harmonisation of national laws or regulations and with the involvement of the EU institutions remaining limited to policies for which the EU-level intervention is explicitly delegated. ${ }^{37}$ Detailed procedural rules of such networks often take the form of non-binding rules; however, due to the general obligation deriving from the fact that effective implementation of the EU law is a matter of common interest, ${ }^{38}$ the principle of loyal cooperation can be regarded to include, among others, a duty to consider, to cooperate, to comply and to assist. ${ }^{39}$ Loyalty, namely, is a general principle that has a function of an aid to interpretation in the light of the Union primary law and as a basis for gap filling. ${ }^{40}$

Cooperation supposes the ordering of the various activities of different actors in the system to enable them to work together effectively. Coordination is managing interdependencies between activities, ${ }^{41}$ the process of interaction that integrates a collective set of independent tasks. ${ }^{42}$ As cooperation, coordination also has a vertical and a horizontal dimension, depending on whether it takes place between the actor of different or the same level in the multilevel European administrative system. The modes of coordination can be distinguished as to whether they rule out exit options (coercive), aim for voluntary adjustment or agreement (cooperative), or establish normative frames of reference (persuasive), depending on the policy and the EU pow-

36 TFEU, Art. 6 and Art. 197.

37 E.G. Heidbreder, Horizontal Capacity Pooling: Direct, Decentralized, Joint Policy Execution, [in:] (eds.) M.W. Bauer, J. Trondal, The Palgrave Handbook... (pp. 45-54.), p. $370,376$.

38 TFEU, Art. 197 (1).

39 M. Klamert, The Principle of Loyalty in EU Law, OUP, Oxford 2014, p. 141. See also, C.F. Amerasinghe, Principles of the Institutional Law..., pp. 176-187.

${ }^{40}$ M. Klamert, The Principle of Loyalty...pp. 247, 251.

${ }^{41}$ P. Debaere, EU Coordination in International Institutions: Policy and Process in GX Forums, Palgrave Macmillan, Basingstoke 2015, p. 24.

${ }^{42} \mathrm{Ch}$. Lequesne, At the Center of Coordination: Staff, Resources and Procedures in the European External Action Service and in the Delegations, [in:] R. Balfour, C. Carta, K. Raik, The European External Action Service and National Foreign Ministries. Convergence or Divergence?, Ashgate, Farnham 2015, p. 46. 
ers on it. ${ }^{43}$ Horizontal capacity pooling is regulated by the EU law at the direct level and means an institutionalized, compulsory, direct networking between competent authorities that is facilitated by supranational technical coordination tools. Under horizontal coordination, administrative capacities (and costs) remain national and are not conferred to the Commission or the EU-level agencies. ${ }^{44}$ Regulating vertical coordination is rare in the system and characterise mainly the relationship between the EU institutions and their subordinated organs, however, "pursuant to the principle of sincere cooperation, the Union and the Member States shall, in full mutual respect, assist each other in carrying out tasks which flow from the Treaties." 45 This means a general definition of the principle of solidarity ${ }^{46}$ among all actors of the European administration.

The common element of all the activity of composite administration which must correspond to the principles that are the basics of the EU and whose respect is also required by Member States' administration is the rule of law and the principle of good administration. ${ }^{47}$

\section{Organisational structure of consular protection policy and the principles in action}

\section{Consular service in case of crisis and the EU competences}

Mostly, internal aspects of public administration are discussed; however, the execution of public policies involves also external branches which provide certain administrative services for citizens abroad. ${ }^{48}$

\footnotetext{
${ }^{43}$ Benz (2015), pp. 35, 37; see in detail: pp. 38-40.

44 E.G. Heidbreder, Horizontal Capacity Pooling..., pp. 378-379.

45 TEU, Art. 4 (3), cf. Art. 3.

${ }^{46}$ See the definitive provisions on solidarity in the Treaties: A. McDonnell, Solidarity, Flexibility..., pp. 61-64.

47 TEU, Art. 6; the EU Charter Preamble and Art. 41; A. von Bogdandy, General Principles..., p. 1919.; See also J. Wakefield, The Right to Good Administration, Kluwer Law International, Alphen aan den Rijn 2007, pp. 21-26.

${ }^{48}$ Consular Protection Directive, Art. 9.
} 
Among these actions, consular protection procedure has outstanding importance. It has always been accepted and acknowledged in international law as a manifestation of personal sovereignty of states to offer certain services for own nationals ${ }^{49}$ in the territory of other states but it has always been a prerogative of each state to decide if and how to regulate such issues and, of course, this being an activity in the foreign territory, all depended on the consensus between the countries concerned..$^{50}$ It correctly used to fall under absolute state discretion whether and how to ensure support to its citizens but since the EU invented the concept and rights inherent to the EU citizenship, the declared consular protection of the EU citizens in third countries is a fundamental right. The EU enabled the citizens to turn to any consular authorities of any Member States if their own state lacks representation in third countries. ${ }^{51}$ As a matter of fact, according to data of 2016, all Member States are represented in only four countries in the world: the US, Russia, India and China. The Commission noted that in 2015 almost 7 million EU citizens travelled to or lived in a country where their national state has no representation and this number is expected to increase. ${ }^{52}$ Therefore, the relevance of such basic right is being revaluated.

In principle, the relevant EU norms made no changes to the substantive rules of consular protection and instead of harmonisation, which is out of the scope of its competences, an equal treatment clause was introduced in certain situations stipulating that the consular authority of the Member State should ensure the same protection to any EU citizens as it would to its own nationals. ${ }^{53}$ Meanwhile, the issue of consular protection in third countries concerns not only funda-

${ }^{49}$ Cf. Vienna Convention on Consular Relations, Vienna, 24 April 1963, 596 UNTS 261 [VCCR], Arts. 7-8.

50 VCCR Art. 4.

51 TFEU, Art. 20.2 c); Art. 23.

52 European Commission - Press release, EU consular protection rules: better protection for European citizens abroad, Brussels, 20 April 2015; http://europa.eu/rapid/ press-release_IP-15-4803_hu.htm (accessed on 10.10.2017). See also, A. Kaczorowska-Ireland, European Union Law, Routledge, London 2016, p. 704.

${ }^{53}$ K. Krūma, EU Citizenship, Nationality and Migrant Status: An Ongoing Challenge, Martinus Nijhoff Publishers, Boston-Leiden 2013, p. 168. 
mental rights, but this element of citizenship policy is strongly merging with the continuously developing foreign policy of the EU via crisis management. This leads to the involvement of the EU foreign policy organs into the administrative procedure of consular protection in third countries. It was the Consular Protection Directive of 2015 which reformed the former regime by expressis verbis creating a unique system of collaboration of organs and authorities, from both levels of European administration, which have competences related to consular protection in third countries, mainly in case of crisis. ${ }^{54}$ The EU nationals undertake more than 180 million journeys outside the EU per year, which gave incentive to strengthen cooperation and coordination in consular protection. ${ }^{55}$

In general, Member States do not need the assistance of the EU as consular assistance and protection are after all exclusive national competencies and only the equal treatment is required whatever the laws and regulation of the Member State is on consular protection measures. The EU rules and organs appear in the procedure only under their own competence in crisis management in case of natural or man-made disasters when a mass of the EU citizens is concerned. The EU neither has competency to regulate consular protection, nor are its institutions and organs entitled to act as consular authorities but the common foreign and security policy (CFSP) must be defined and implemented by the European Council and the Council acting unanimously, except where the TEU/TFEU provide otherwise, and should be put into effect by the High Representative of the Union for Foreign Affairs and Security Policy (HR/VP) and by Member States. ${ }^{56}$

${ }^{54}$ Council Directive 2015/637 of 20 April 2015 on the coordination and cooperation measures to facilitate consular protection for unrepresented citizens of the Union in third countries and repealing Decision 95/553/EC, OJ L 106, 24.4.2015 [Consular Protection Directive], Chapter 2.

55 In April 2006, the COCON Group estimated these trips at some 180 million per year; cf. Green Paper - Diplomatic and consular protection of Union citizens in third countries (presented by the Commission), Brussels, 28.11.2006, COM(2006)712 final, p. 4 , footnote no. 6 .

56 TEU, Art. 24 (1); 3. Art. 26 (2)-(3); TFEU, Art. 2 (4). 


\section{Organisational structure of the consular protection policy}

The procedure and function of the consular authority basically fall under its delegating state's material and procedure rules as representations are external organisational units of the state administration. Therefore, they are under the direction of a higher authority in a hierarchical system. In Hungary, consular authorities are divisions of the Ministry of Foreign Affairs and the consular officer is under the direction of the minister of foreign affairs. ${ }^{57}$ In case of crisis, that is natural or industrial catastrophes, terrorist attacks or any kind of situation when a mass of the EU citizens need consular assistance on the territory of a third country, the supranational level of the European administration directly appears with the Commission as its vice-president, the HR/VP is responsible for foreign policy, including crisis management..$^{58}$ It also involves the European External Action Service (EEAS), which is a functionally autonomous body under the direction of the HR/VP ${ }^{59}$ and more than 140 delegations $^{60}$ of the EU at local level which are hybrid administrative constructs that combine diplomatic and operational tasks, such as development cooperation and trade $^{61}$ but have no competence to provide consular protection. The

57 Act XLV of 2001 on Consular protection [CPA] 2 (1)-(2); E. Csatlós, Az általános konzuli hatósági együttmüködések elméleti kérdései, Eljárásjogi Szemle, No. 1, 2017 (pp. 33-42.), p. 34.

${ }_{58}$ TEU, Art. 26 (2); Council Decision of 26 July 2010 establishing the organisation and functioning of the European External Action Service (2010/427/EU) [EEAS Decision] Art. 4 (3) a).

59 EEAS decision Art. 1.2; Ch. Lequesne, At the Center of Coordination..., p. 36; See autonomy of EEAS in detail: M. Gatti, European External Action Service: Promoting Coherence through Autonomy and Coordination, BRILL, Leiden 2016, pp. 105-190.

${ }^{60}$ See the EU delegations in the world: https://eeas.europa.eu/headquarters/headquarters-homepage/area/geo_en (accessed on 10.10.2017)

${ }^{61}$ Before the Lisbon Treaty entered into force, this role was fulfilled by the Member State holding the rotating EU Presidency. It might be seen as the loss of power and visibility in comparison to the rotating presidency system. D. Helly, A. Herrero, A. Knoll, G. Galeazzi, A. Sherriff, A Closer Look into EU's External Action Frontline: Framing the Challenges ahead for EU Delegations, ECDPN, Briefing Note, No. 62, March 2014, p. 9; see also: V. Reynaert, The European Union's Foreign Policy since the Treaty of Lisbon: The Difficult Quest for More Consistency and Coherence, The Hague Journal of Diplomacy, Vol. 7, 2012 (pp. 207-226), p. 224. 
consular tasks - help and assistance - are performed by the consular authorities of the Member States, while delegations have a complementary role. ${ }^{62}$ If more Member States are represented at site a Lead State might be entitled with a coordination role for a better sharing of work among representations ${ }^{63}$ as none of the supranational organs are either entitled to perform authority acts or to pursue consular protection procedure instead of Member State consular authorities. It is a domestic competence, although, the EU institutions and organs have direct impact on the evaluation of the EU policy in this field in case of crisis.

The cooperation of the competent institutions and organs is mainly based on coordination. Horizontal coordination is carried out at two main levels. (1) At direct administrative level, the coordination of all the foreign policy issues is the responsibility of the HR/VP ${ }^{64}$ assisted by the EEAS, which also has its own coordination system among its different divisions. ${ }^{65}$ (2) In situ coordination has three main potential actors each of them having their own coordination mechanism. The first actor responsible for coordination is (a) the local EU delegation. The second one is (b) the group of represented Member States who closely cooperate with each other and with the delegation and other potential bodies of the Commission. ${ }^{66}$ They can assign a Lead State among themselves for making the coordination with the other actors of the organisation easier. Hereby it needs to be noted that Member States can take on the role of the Lead State on a voluntary basis, ${ }^{67}$ and apart from the Lead State concept, which is defined in a guideline and not a binding legal norm, there is no reference to which of the represented Member State organ is responsible for coordination. According to the Consular Protection

${ }^{62}$ F. Austermann, European Union Delegations in EU Foreign Policy. A Diplomatic Service of Different Speeds, Palgrave Macmillan, Basingstoke 2014, p. 57.

${ }^{63}$ European Union guidelines on the implementation of the consular Lead State concept (2008/C 317/06), OJ C 317, 12.12.2008 [Lead State Guidelines], Art. 2.1-2.4.

${ }_{64}$ TEU, Art. 26 (2).

65 EEAS Decision, Art. 4.

${ }^{66}$ Consular Protection Directive, Preamble (16)-(17), Art. 10.1.; 11.

${ }^{67}$ Lead State Guidelines, Introduction (2); (5). 
Directive elaborated in 2015, Member States represented in a third country shall closely cooperate with each other and share information to ensure efficient assistance for unrepresented citizens and coordinate contingency plans among themselves and with the EU delegation to ensure that unrepresented citizens are fully assisted in the event of a crisis. ${ }^{68}$ Further details, like the assignment of one responsible actor to manage the process of an evacuation, for instance, and deal with the involvement of the EU capacities, is the subject of further intergovernmental negotiations of Member States. ${ }^{69}$ In addition, such negotiation does not create a right to give orders for the delegations or in reverse, nor does subordinate consular authorities to the EU organs in the system. Upon request by Member States' consular authorities, the delegations support the Member States in their diplomatic relations and in their role of providing consular protection to citizens of the Union in third countries on a resource-neutral basis. ${ }^{70}$ They can also request to be supported by existing intervention teams at the Union level, including consular experts, in particular from unrepresented Member States, and by instruments such as the crisis management structures of the EEAS and the Union Civil Protection Mechanism. ${ }^{71}$ The Member States concerned should, whenever possible, coordinate such requests among each other and with any other relevant actor to ensure the optimal use of the Union Mechanism and avoid practical difficulties on the ground. The Lead State, if designated, should be in charge of coordinating of any support provided for unrepresented citizens. ${ }^{72}$

${ }^{68}$ Consular Protection Directive, Preamble (2), Art. 13.

69 Consular Protection Directive, Preamble (19), Art. 7 (2)-(3).

${ }^{70}$ See EEAS Decision Art. 5(9); D. Helly et al., A Closer Look into EU's External Action.., pp. 8-10.

${ }^{71}$ Consular Protection Directive, Art. 13 (4); Decision No 1313/2013/EU of the European Parliament and of the Council of 17 December 2013 on a Union Civil Protection Mechanism, Article 16, point 17. The civil protection mechanism is an operative instrument, which essentially aims at facilitating the mobilisation of immediate in-kind assistance for disasters both within and outside the EU. M. Gestri, EU Disaster Response Law: Principles and Instruments, [in:] (ed.) A. de Guttry, International Disaster Response Law, Asser, The Hague 2012 (pp. 106-128), p. 118.

${ }^{72}$ Lead State Guidelines, 2. 
To describe the relationship between the different levels and different actors of European administration of consular policy, the words "coordinate" and "support" are used often. Even if none of these words are defined by any normative texts, they must not suggest obligation. The aim is to synthesize efforts but without the coercive force of persuasion or direct order to make obligations, although accountability, predictability, and common understanding are presumed. ${ }^{73}$

The system of European administration on consular protection lacks the classical hierarchical structure of state administration and vertical coordination is regulated by decision only in the case of the EEAS and its delegations. According to the relevant legal and non-legal acts of the EU acquis, none of the EU institutions or other bodies is entitled to direct consular authorities of Member States and practice such influence that would reduce their autonomy, or to receive their consular tasks. The consular authorities stay under the direction of their domestic superior authority, although the Member States' authorities should closely cooperate and coordinate with one another and with the EU, in particular the Commission and the EEAS, in a spirit of solidarity. ${ }^{74}$

Under these general principles, in absence of harmonisation in material rules on foreign policy and consular protection, would vertical cooperation have an indirect impact making the EU organs a coercive power on external Member State organs? The principle of loyal cooperation might urge the effective execution and evaluation of a fundamental right of citizenship to overrule the shortage on organisational rules but, in the meantime, neither the implementation of foreign policy, nor the charter may extend the field of application of the EU law or establish any new power or task for it, or modify powers and tasks

${ }^{73}$ Ch. Lequesne, At the Center of Coordination..., p. 46.

${ }^{74}$ Solidarity is a constitutional and European value. N. Chronowski, Dignity and Solidarity - Lost in Transition. The Case of Hungary, MTA Law Working Papers, No. 15, 2017, pp. 3-5. See also: TEU, Art. 2; cf. in particular CFSP: TFEU 2221 (b); Council Decision of 24 June 2014 on the arrangements for the implementation by the Union of the solidarity clause (2014/415/EU), OJ L 192, 1.7.2014, Art. 4; 5. On the meaning of solidarity, see: M. Klamert, The Principle of Loyalty... pp. 35-41. 
as defined in the TEU-TFEU. The rules for the EEAS and foreign policy may not affect the existing legal basis, responsibilities, and powers of each Member State in relation to the formulation and conduct of the EU foreign policy, national diplomatic service, and relations with third countries. ${ }^{75}$ Meanwhile, many debates support the expansion of the delegations' competency to take over some administrative functions to issue of a Schengen visa and performance of some basic consular protection activity. ${ }^{76}$ In the name of the subsidiary principle and the constitutional allocation of competences in the Treaties, along with financial and institutional simplification prospects, the smaller states welcome the idea and would happily save some money with closing their consulates or being represented by the EU delegation where they were not before, but absolutely rejected by the dominant large states which are afraid of losing the rest of their external sovereignty and political interests by such step. ${ }^{77}$

\section{Concluding remarks}

The European administrative organisation is a multilevel structure which is more than a European administrative space with different kinds of networks of authorities in different policies. Its structure is based on the transfer of power from Member States and is functioning on the basis of institutional autonomy and loyal cooperation of competent authorities of both levels with an intense horizontal coordination at the supranational centre.

75 14. Declaration to the Treaties, EU Charter Art. 51 (2); TEU, Art. 40 (1); EEAS Decision Article 4 (3)(a); cf. TFEU, Art. 352. See, A. Dashwood, Article 308 EC as the Outer Limit of Expressly Conferred Community Competence, [in:] (eds.) C. Barnard, O. Odudu, The Outer Limits... (pp. 35-44), p. 43.

${ }^{76}$ R. Balfour, K. Raik, Equipping the European Union for the 21st Century. National Diplomacies, the European External Action Service and the Making of EU Foreign Policy, FIIA Report 36, 2013, pp. 37-38.

77 Ch. Lequesne, At the Center of Coordination..., p. 48-49; cf. R. Whitman, Europe's Changing Place in the World and Challenges to European Diplomacy, [in:] R. Balfour, C. Carta, K. Raik, The European External Action Service... (pp.17-30), p. 25. 
Many questions and contradictions arise about the institutional and structural system of consular protection. As the EU acquis is continuously developing, the classical structural thoughts on the European administration should be re-considered. Given the fact that in the area which significantly affects foreign policy, external sovereignty, and international relations of a state to which the EU has strictly limited competences, the strongest coordination force is the basic principle of loyal cooperation and solidarity but it does not make the structure effective, operational and conforming to the rule of law. The challenging part is the vertical relationship of the actors. In fact, at the local level, only delegations are under the effective direction of the HR/VP and the president of the EEAS, who both represent the EU interests, but the consular tasks are performed by the consular authorities of Member States because they are empowered to do so, however, these latter category falls outside their scope.

Principles cannot create a competence and cannot provide a direct legal basis for a measure at the EU level. Indeed, principles primarily indicate how a competence should be used, and therefore they guide those who fulfil obligations. ${ }^{78}$

${ }^{78}$ A. McDonnell, Solidarity, Flexibility..., p. 66. 